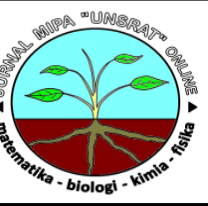

\title{
Analisis Kandungan Klorofil Pada Beberapa Posisi Anak Daun Aren (Arenga pinnata) dengan Spektrofotometer UV- Vis
}

\author{
Lydia Kamagia*, Julius Pontoha, Lidya I. Momuata \\ aJurusan Kimia, FMIPA, Unsrat, Manado
}

\begin{tabular}{l} 
K A T A K U N C I \\
\hline Daun aren (Arenga pinnata) \\
Klorofil \\
Analisis
\end{tabular}

\begin{abstract}
A B S T R A K
Tanaman aren merupakan salah satu tanaman penghasil gula bagi kehidupan manusia. Tanaman ini merupakan tanaman penghasil gula tertinggi daripada tanaman tebu dan tanaman bit. Kemampuan tanaman aren dalam memproduksi gula sangat berhubungan dengan kandungan klorofil pada bagian daun. Penelitian ini dilakukan untuk mengembangkan metode analisis klorofil pada daun dan menentukan posisi anak daun yang memiliki kandungan klorofil tertinggi. Analisis kandungan klorofil dilakukan dengan metode ektraksi pelarut yang absorbansinya dibaca pada spektrofotometer UV-Vis. Kandungan klorofil a yang terdapat pada daun aren bervariasi, yaitu berkisar 22 - $39 \mu \mathrm{g} / \mathrm{mL} ; 1,5$ - 2,3 mg/g ; 633 $1.000 \mu \mathrm{mol} / \mathrm{m}^{2}$ sedangkan untuk klorofil b yang terdapat pada daun aren bervariasi sekitar 6 - $10 \mu \mathrm{g} / \mathrm{mL} ; 0,4-0,7 \mathrm{mg} / \mathrm{g} ; 170-293 \mu \mathrm{mol} / \mathrm{m}^{2}$.Posisi anak daun pada daun memiliki kandunngan klorofil yang lebih tinggi pada bagian atas, sedangkan yang terendah pada bagian bawah. Pada posisi kiri pada daun aren,kandungan klorofilnya lebih tinggi dibandingkan pada posisi kanan,sedangkan posisi pangkal, tengah, dan ujung pada anak daun hampir sama kandungan klorofilnya.
\end{abstract}

K E Y W O R D S

Palm Leaf (Arenga pinnata) Chlorophyll

Analysis

\begin{abstract}
A B S T R A C T
Sugar palm is one of the sugar-producing plants for human life. This plant can produce sugar higher than a sugar-producing plant with sugar cane and beet plant. The ability of sugar palm in producing sugar is related to chlorophyll content in the leaf. This research was conducted to develop the method of chlorophyll analysis in the leaf and determine the position of leaflet that have the highest chlorophyll content. Analysis of chlorophyll content was performed by solvent extraction method that absorbance was read on UV-Vis spectrophotometer. The content of chlorophyll present in palm leaves varies, ranging from 22 - $39 \mu \mathrm{g} / \mathrm{mL}$; $1.5-2.3 \mathrm{mg} / \mathrm{g}$ or $633-$ $1,000 \mu \mathrm{mol} / \mathrm{m}^{2}$ whereas for chlorophyll $\mathrm{b}$ present in sugar palm varies from about 6 - $10 \mu \mathrm{g} / \mathrm{mL} ; 0.4-0.7 \mathrm{mg} / \mathrm{g}$ or $170-293 \mu \mathrm{mol} / \mathrm{m}^{2}$. The leaflet position on the leaves has a higher chlorophyll content at the top, while the lowest is at the bottom. In the left position on the palm leaves, chlorophyll content is higher than the right position, while the position of base, middle, and end of the leaflet leaves almost the same content.
\end{abstract}

TERSEDIA ONLINE

1 Agustus 2017

1. Pendahuluan

Tanaman aren merupakan tanaman serbaguna. Produk utama tanaman aren adalah nira aren yang mengandung sukrosa 11-16 \%. Bahan ini digunakan untuk pembuatan gula merah, berbagai minuman, dan sebagai sumber bahan bakar nabati. Berbagai produk tanaman aren lainnya yang dimanfaatkan oleh manusia adalah batang, daun, buah, dan ijuk sebagai perabot rumah tangga serta sebagai produk pangan, contohnya kolang-kaling ( Suseno, 1991).

Produk utama tanaman aren yang didapatkan dari nira aren adalah gula aren. Pohon aren memiliki kemampuan untuk menghasilkan produk gula yang

*Corresponding author: Jurusan Kimia FMIPA UNSRAT, Jl. Kampus Unsrat, Manado, Indonesia 95115; Email address: kamagilydiapriskila@gmail.com Published by FMIPA UNSRAT (2017) 
lebih tinggi (25 ton/ ha/ thn) dibandingkan dengan tanaman tebu (11 ton/ha/thn), dan tanaman bit (12 ton/ ha/ thn). Produksi gula pada tanaman aren sangat bervariasi dari $11 \%$ sampai $17 \%$, sehingga perlu dilakukan analisis pada tanaman aren untuk memperoleh informasi mengenai potensi dari tanaman aren tersebut untuk menghasilkan gula (Pontoh dan Smits, 2015).

Produksi gula pada tanaman aren dipengaruhi oleh kandungan pati pada tanaman aren karena pati dapat terhidrolisis menjadi gula. Sebelumnya telah dilakukan penelitian untuk mengetahui keadaan tanaman dan potensinya untuk menghasilkan gula menggunakan analisis pengukuran kandungan pati dalam empulur batang sebagai salah satu indikator untuk mengetahui potensi tanaman aren dalam memproduksi gula. Namun analisis dengan metode pengukuran pati dalam empulur batang akan melukai tanaman aren ketika mengambil pati tersebut sehingga besar kemungkinan tanaman aren menjadi mati ( Manatar et al., 2012).

Selain kandungan pati yang mempengaruhi kemampuan produksi gula, ternyata jumlah kandungan klorofil pada daun aren juga mempengaruhi kemampuan produksi gula pada tanaman aren karena gula merupakan produk primer dari proses fotosintesis. Proses fotosintesis terjadi di daun saat karbon dioksida dan air diubah menjadi gula dengan bantuan energi foton dari cahaya matahari. Kemudian energi foton tersebut akan ditangkap oleh klorofil untuk dilanjutkan ke pusat reaksi (Pratiwi dan Alrasjid, 1989).

Peran klorofil untuk menangkap energi dari cahaya matahari dan melanjutkan ke pusat reaksi fotosintesis sangatlah penting. Klorofil merupakan senyawa siklik tetrapirol yang mampu menyerap foton karena ikatan konjugasi dalam satu struktur. Oleh karena itu, jumlah klorofil akan sangat menentukan produksi gula dari fotosintesis (Nurdin et al., 2009).

Kandungan klorofil pada daun bervariasi dari satu jenis tanaman dengan tanaman lainnya. Kandungan klorofil bahkan bervariasi antara berbagai varietas tanaman dalam satu spesies. Misalnya pada tanaman puring kandungan klorofil antara varietas tanaman puring bor merah, puring cobra, dan puring lokal memiliki perbedaan kandungan klorofil. Umur daun juga mempengaruhi adanya variasi kandungan klorofil pada tanaman (Gogahu et al., 2016).

Selain umur dan varietas daun, kandungan klorofil juga bervariasi dilihat dari posisi daun dalam satu tanaman. Analisis kandungan klorofil pada tanaman kelapa sawit menunjukkan bahwa selain umur daun, ternyata posisi daun yang berbeda pada umur daun yang sama, juga menunjukkan adanya variasi jumlah kandungan klorofil pada daun tersebut ( Mustafa et al., 2015)

Ciri-ciri daun tanaman aren hampir sama dengan tanaman kelapa sawit karena termasuk dalam satu famili yaitu palmae. Daun tanaman aren merupakan daun majemuk yang menyirip ganjil. Secara morfologi, daun yang majemuk pada daun aren disebut anak daun dan anak daun memiliki ciriciri, yaitu daunnya panjang, berbentuk seperti pita bergelombang, dan berwarna hijau gelap (Wisnuwati, 1996).

Analisis kandungan klorofil pada daun aren dilakukan untuk mendapatkan informasi tentang kandungan klorofil di beberapa posisi daun serta memberikan pengetahuan mengenai teknik pengambilan sampel daun yang menjadi salah satu indikator untuk mengetahui kemampuan tanaman aren memproduksi gula.

Analisisis kandungan klorofil pada umumnya dilakukan dengan mengekstrak daun menggunakan pelarut kemudian kandungan klorofil ditentukan dengan spektrofotometer UV-Vis. Salah satu contoh pelarut yang digunakan untuk analisis kandungan klorofil yaitu metanol (Sumanta et al., 2014).

\section{Material dan Metode \\ Alat dan Bahan}

Alat-alat yang akan digunakan dalam penelitian ini adalah alat-alat gelas, neraca analitik, alat sentrifugasi, lumpang dan alu, lemari pendingin, cool box, alummunium foil, gunting, one hole punch dengan diameter $6,4 \mathrm{~mm}$, alat pengukur panjang, dan spektrofotometer UV-Vis (Shimadzu UV-Vis 1800).

Bahan-bahan yang akan digunakan adalah sampel daun aren, standar klorofil a dan klorofil b (Sigma Aldrich), methanol PA(Merck), tissue, akuades, label, dan kantong plastik untuk menyimpan sampel.

\section{Preparasi Sampel Daun Aren}

Daun aren diambil dari daun yang berada di posisi tengah dari tajuk tanaman. Sampel diambil dari anak daun pada posisi ujung, atas, tengah, dan bawah (Gambar 1). Selanjutnya anak daun diambil kiri dan kanan pada posisi anak daun. Lembar daun pada anak daun dibedakan atas 3 bagian, yaitu: pangkal, tengah, dan ujung. Sampel diambil dari setiap bagian tersebut dengan cara dipotong dengan menggunakan one hole punch sebanyak 10-11 potongan, tergantung pada berat sampel tersebut. Setiap sampel diusahakan untuk mencapai berat 0,1 gram (100 mg). Selanjutnya sampel segera diberi label dan diletakkan dalam kantung plastik, kemudian sampel tersebut dimasukkan ke dalam lemari pendingin.

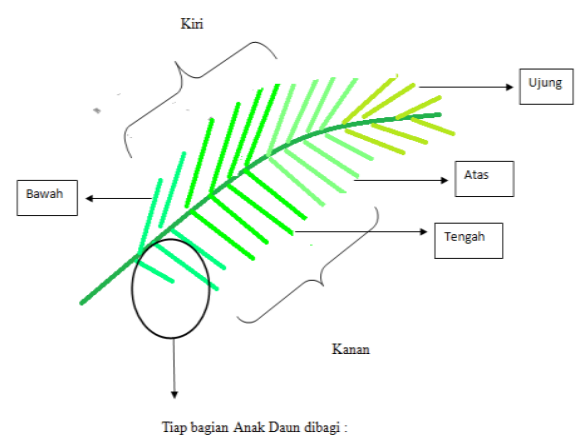




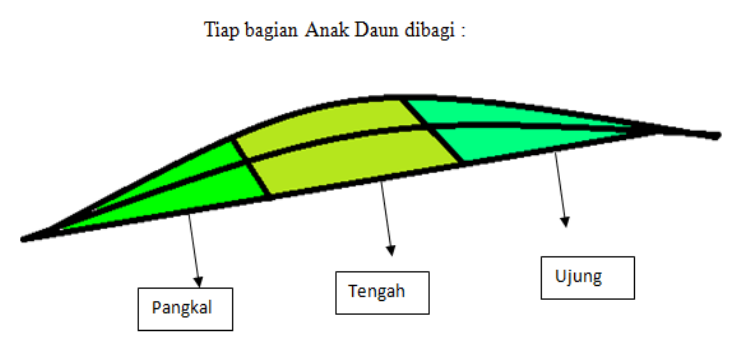

Gambar 1. Posisi Pengambilan Sampel Daun Aren

\section{Ekstraksi Sampel dan Karakterisasi Absorbansi Klorofil ( Porra et al, 1989) :}

Sampel yang akan dianalisis, diekstrak terlebih dahulu menggunakan metanol. Sebanyak 0,1 gram sampel dan $2 \mathrm{~mL}$ pelarut dimasukkan ke dalam wadah lumpang, kemudian dihaluskan dengan cara digerus menggunakan alu. Lalu sampel yang telah digerus tersebut dimasukkan ke dalam gelas ukur. Setelah itu, lumpang dan alu yang telah digunakan untuk menghaluskan sampel, dibilas dengan $1,5 \mathrm{~mL}$ pelarut sebanyak tiga kali. Tujuannya untuk melarutkan sisa-sisa sampel yang masih tertinggal.

Pelarut yang digunakan untuk membilas sisasisa sampel yang terdapat pada lumpang dan alu tersebut, dimasukkan bersama-sama dengan sampel yang telah dihaluskan dengan pelarut tadi ke dalam gelas ukur. Ekstrak tersebut ditera hingga mencapai volume $8 \mathrm{~mL}$. Lalu ekstrak tersebut dimasukkan ke dalam tabung centrifuge dan disentrifugasi selama 10 menit dengan kecepatan $2.500 \mathrm{rpm}$. Supernatan yang diperoleh diencerkan menjadi $1 \mathrm{~mL}$ ekstrak dilarutkan ke dalam $4 \mathrm{~mL}$ metanol dan dibaca absorbansinya dengan spektrofotometer UV-Vis (Shimadzu UV-Vis 1800) pada panjang gelombang $665 \mathrm{~nm}$ dan $652 \mathrm{~nm}$.

\section{Penentuan Konsentrasi Klorofil pada Daun}

\section{Analisis Konsentrasi Klorofil dengan Rumus menurut Porra et al (1989) :}

Absorbansi yang telah dibaca pada panjang $665 \mathrm{~nm}$ dan $652 \mathrm{~nm}$ dimasukkan ke dalam rumus :

[Ch a] = 16,29 A665 - 8,54 A652

[Ch b] = 30,66 A652 - 13,58 A665

Keterangan : $[\mathrm{Ch}$ a] $=$ konsentrasi klorofil a

$$
\text { [Ch b] = konsentrasi klorofil b }
$$

Dari rumus tersebut didapatkan konsentrasi klorofil yang ada pada daun aren.

\section{Analisis Konsentrasi Klorofil Menurut Kurva Standar yang dibuat}

Sebanyak $1 \mathrm{mg}$ standar klorofil a dilarutkan ke dalam $25 \mathrm{~mL}$ metanol sehingga didapatkan konsentrasi sebesar $40 \mu \mathrm{g} / \mathrm{mL}$. Kemudian diencerkan ke beberapa konsentrasi. Pada larutan standar klorofil a diencerkan dengan konsentrasi : 1,$25 ; 2,5 ; 5$; dan $10 \mu \mathrm{g} / \mathrm{mL}$. Pada larutan standar klorofil b diencerkan dengan konsentrasi : 0,$75 ; 1,5$ ; 3 ; dan $6 \mu \mathrm{g} / \mathrm{mL}$. Data absorbansi yang telah dibaca dengan spektrofotometer UV- Vis (Shimadzu 1800), dihitung menggunakan persamaan regresi dari kurva standar tersebut untuk mendapatkan nilai konsentrasi dari klorofil.

\section{Hasil dan Pembahasan}

\section{Panjang Gelombang Klorofil a dan Klorofil b}

Reaksi cahaya saat proses fotosintesis adalah akibat langsung penyerapan foton oleh molekulmolekul pigmen seperti klorofil. Foton dengan panjang gelombang antara 390-760 nm (photosynthetically active radiation/PAR) yang memiliki energi yang cocok untuk fotonsintesis (Gardner, 1991). Hal ini sesuai dengan hasil scanning panjang gelombang yang telah dilakukan, bahwa panjang gelombang yang terlihat pada hasil scanning berada di sekitar panjang gelombang 400 sampai $700 \mathrm{~nm}$.

Porra et al.(1989) melaporkan bahwa hasil scanning panjang gelombang dari klorofil berada di sekitar 400 hingga $700 \mathrm{~nm}$. Pada klorofil a, puncak tertinggi berada pada panjang gelombang $665 \mathrm{~nm}$, sedangkan untuk klrofil b, puncak tertinggi berada pada panjang gelombang $652 \mathrm{~nm}$. Jika standar klorofil a dan klorofil b dicampur 1 : 1 (2mL : $2 \mathrm{~mL})$ maka akan didapatkan hasil scanning panjang gelombang yang memiliki puncak pada $665 \mathrm{~nm}$. Klorofil a memiliki absorbansi maksimum pada panjang gelombang $665 \mathrm{~nm}$ dan klorofil b pada 652 $\mathrm{nm}$.

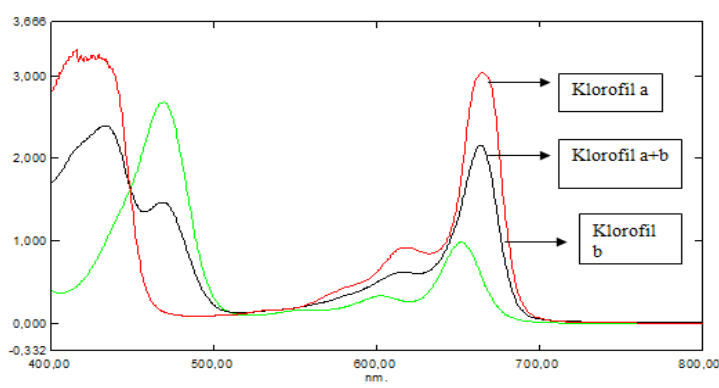

Gambar 2. Spektra dari hasil scanning larutan standar klorofil a, klorofil b dan klorofil $a+b$

Hasil scanning ekstrak metanol daun aren tertera pada Gambar 3. Hasil scanning larutan standar klorofil $a+b$ memiliki pola yang sama dengan hasil scanning daun aren yang terdapat di bagian pangkal, tengah, dan ujung pada anak daun di posisi kiri anak daun terhadap tandan daun aren yang terletak di bagian bawah dari tandan daun.

Pada posisi yang lainnya, scanning panjang gelombang daun aren memiliki pola yang sama, namun pada penyajian Gambar 3, hanya diambil beberapa bagian saja yang mewakili hasil scanning panjang gelombang pada daun aren. Hal ini membuktikan bahwa sampel yang diamati adalah sampel yang mengandung klorofil a dan klorofil b, karena klorofil a dan klorofil b terdapat pada tumbuhan tingkat tinggi seperti pada daun pohon aren. Tumbuhan tingkat tinggi adalah tumbuhan yang memiliki batang, akar, dan daun sejati, seperti tumbuhan yang tergolong spermatophyta 
(tumbuhan berbiji) dan tanaman aren termasuk pada golongan spermatophyta (Champbell, 2002).

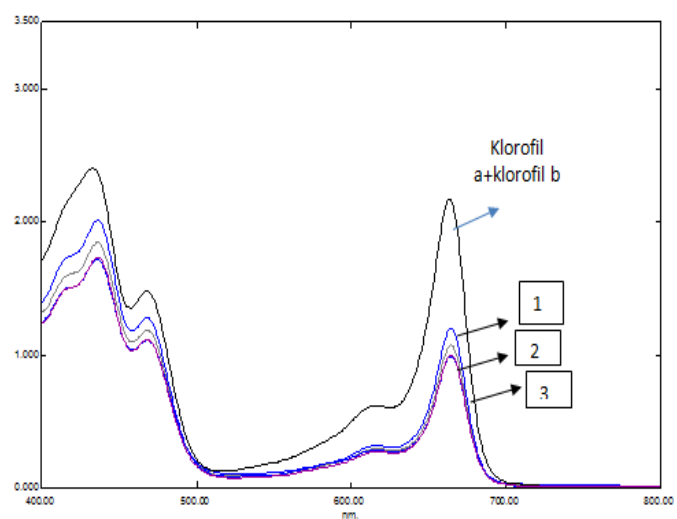

Gambar 3. Spektra dari hasil scanning larutan standar klorofil $a+b$ dan beberapa hasil scanning dari ekstrak daun aren: (1) pangkal (2) tengah (3) ujung

Perbandingan Konsentrasi Klorotil yang Dihitung dengan Kurva Standar Klorofil dan Rumus Menurut Porra et al.( 1989)

Pembuatan kurva standar klorofil a dan klorofil b telah dilakukan dengan cara memasukkan data konsentrasi dan absorbansi di program excel sehingga didapatkan kurva standar yang memiliki persamaan regresi linear $y=0,0836 x+0,0163$ (Gambar 4).

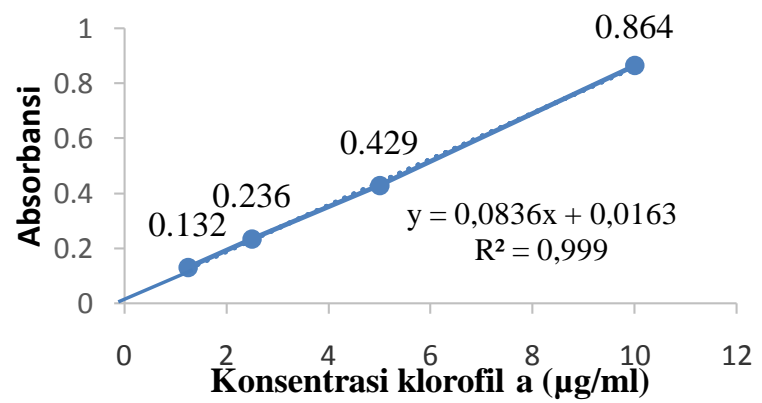

Gambar 4. Kurva standar klorofil a

Pada klorofil b juga didapatkan persamaan regresi linear $y=0,160 x+0,018$. Kurva standar klorofil b dapat dilihat pada Gambar 5 .

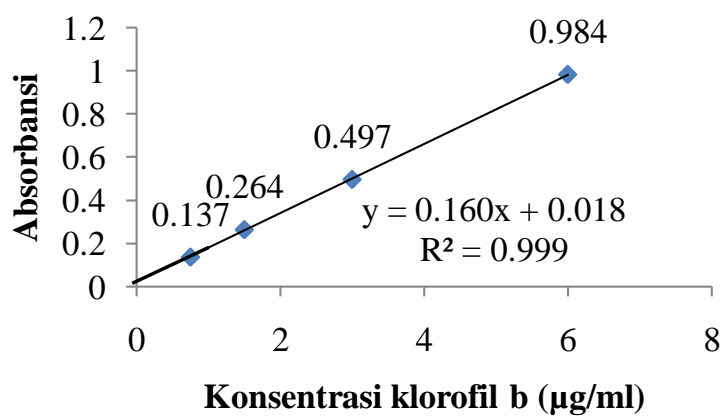

Gambar 5. Kurva standar klorofil b

Pengukuran karakter fisiologi tanaman seperti kandungan klorofil, merupakan salah satu pendekatan untuk mempelajari pengaruh karakter tersebut terhadap pertumbuhan dan hasil produksi pada tanaman yang berkaitan erat dengan laju fotosintesis. Oleh sebab itu informasi mengenai kandungan klorofil a dan klorofil b pada tanaman sangat diperlukan, karena merupakan salah satu indikator untuk mengetahui potensi tanaman dalam memproduksi hasil yang dapat dimanfaatkan manusia ( Li et al., 2006).

Pada Gambar 7 terlihat bahwa kandungan klorofil a di posisi anak daun aren memiliki perbedaan satu sama lain. Terlihat bahwa kandungan klorofil a pada posisi atas daun aren lebih tinggi daripada posisi lainnya, sedangkan posisi bawah daun aren lebih rendah dibandingkan dengan posisi lainnya.

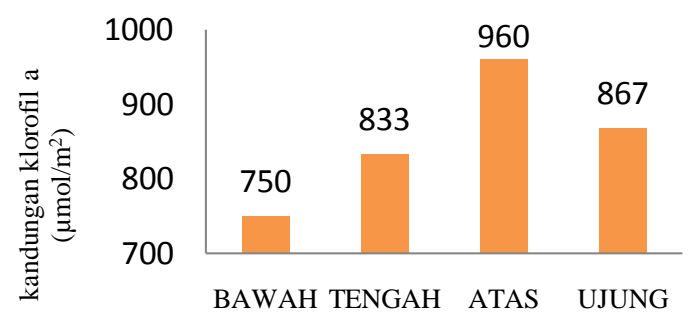

Gambar 7. Pengaruh Posisi Anak Daun Aren Terhadap Kandungan Klorofil a

Gambar 8 menunjukkan kandungan klorofil a di bagian pangkal, tengah, dan ujung. Kandungan klorofil a pada ketiga posisi tersebut relatif sama satu dengan yang lain.

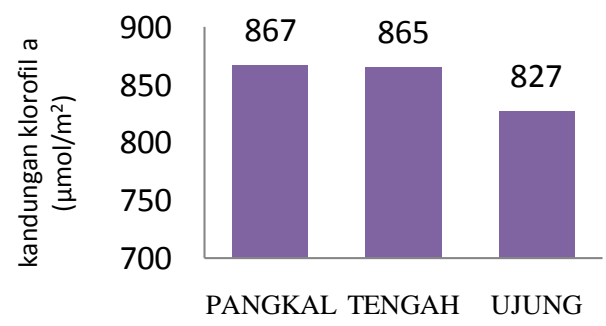

Gambar 8. Pengaruh Posisi Sampel pada Satu Anak Daun Terhadap Kandungan Klorofil a

Pada Gambar 9 dapat dilihat bahwa posisi kiri daun aren dan posisi kanan daun aren memiliki perbedaan. Posisi kiri daun aren (tiap-tiap anak daun aren pada tandan daun) memiliki nilai kandungan klorofil a yang lebih banyak daripada posisi kanan daun aren.

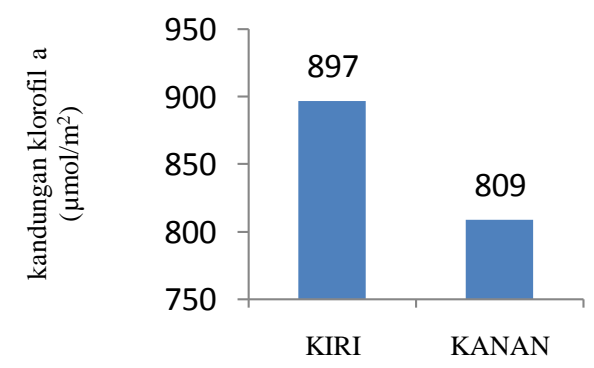

Gambar 9.Pengaruh Posisi Kiri dan Posisi Kanan Pada Daun Terhadap Kandungan Klorofil 
Pada Gambar 10 terlihat bahwa kandungan klorofil b di posisi anak daun aren memiliki perbedaan satu sama lain. Terlihat bahwa kandungan klorofil b pada posisi atas daun aren lebih tinggi daripada posisi lainnya, sedangkan posisi bawah daun aren lebih rendah dibandingkan dengan posisi lainnya.

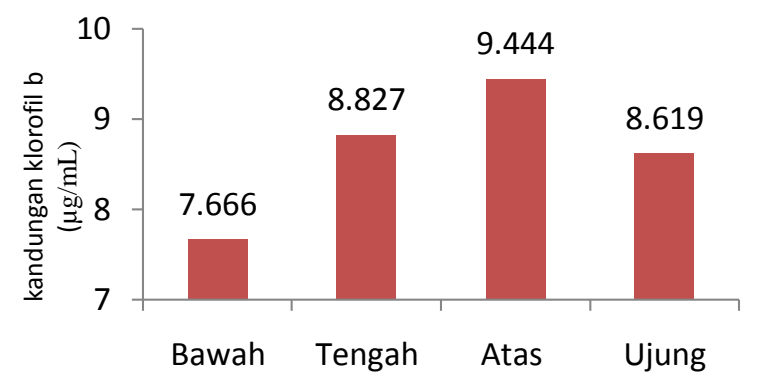

Gambar 10. Pengaruh Posisi Anak Daun pada Daun Terhadap Kandungan Klorofil b

Gambar 11 menunjukkan kandungan klorofil b di bagian pangkal, tengah, dan ujung. Kandungan klorofil b pada ketiga posisi tersebut relatif sama satu dengan yang lain.

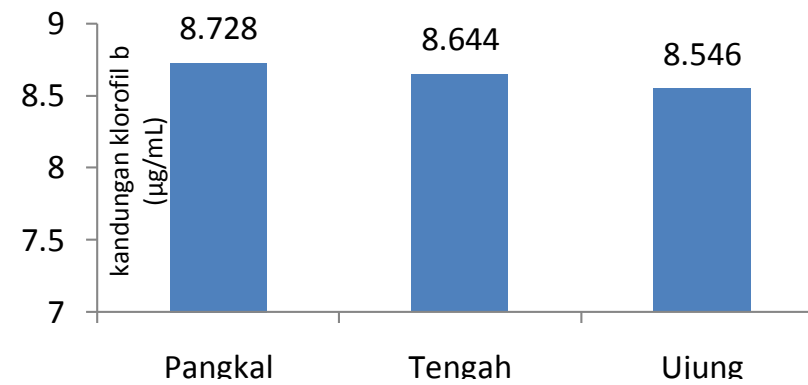

Gambar 11. Pengaruh Posisi Sampel pada Satu

Anak Daun Terhadap Kandungan Klorofil b

Pada Gambar 12 dapat dilihat bahwa posisi kiri daun aren dan posisi kanan daun aren memiliki perbedaan. Posisi kiri daun aren (tiap-tiap anak daun aren pada tandan daun) memiliki nilai kandungan klorofil b yang lebih banyak daripada posisi kanan daun aren.

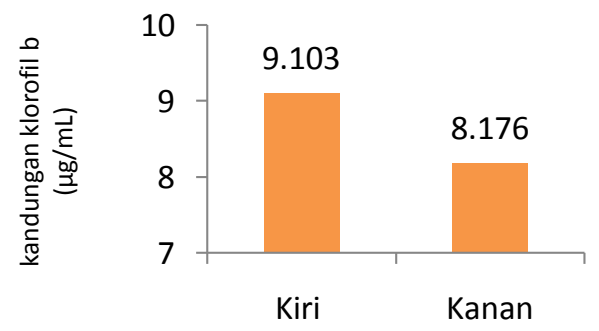

Gambar 12.Pengaruh Posisi Kiri dan Posisi Kanan Pada Daun Terhadap Kandungan Klorofil b

Terlihat bahwa rata-rata kandungan klorofil lebih banyak di bagian kiri dibandingkan pada bagian kanan daun aren.
Posisi daun bagian atas pada tandan daun, memiliki nilai kandungan klorofil yang lebih tinggi, sedangkan pada posisi bagian bawah daun aren terlihat bahwa pada posisi daun pada tandan daun memiliki nilai konsentrasi klorofil yang lebih kecil dibandingkan pada posisi yang lainnya. Sedangkan kandungan klorofil untuk satu anak daun yang dibagi menjadi 3 bagian yaitu : pangkal,tengah, dan ujung memiliki nilai kandungan klorofil yang hampir sama. Hal ini berarti letak anak daun pada posisi daun bagian kiri dan kanan pada tandan daun serta letak anak daun pada masing-masing bagian daun (bawah, tengah, atas, dan ujung) pada tandan mempengaruhi konsentrasi klorofil. Kandungan klorofil yang berbeda-beda pada posisi kiri dan kanan anak daun pada tandan dan posisi masingmasing anak daun pada bagian (bawah, tengah, atas, dan ujung) pada tandan dapat dipengaruhi karena lebih banyak terkontaminasi cahaya matahari sedangkan pada bagian bawah, kontaminasi dengan cahaya matahari lebih sedikit sehingga konsentrasi klorofil lebih sedikit.

\section{Kesimpulan}

Berdasarkan hasil penelitian dapat disimpulkan bahwa :

1. Kandungan klorofil a yang terdapat pada daun aren berdasarkan ketiga satuan yang dipakai bervariasi, yaitu 22 - $39 \mu \mathrm{g} / \mathrm{mL} ; 1,5$ - 2,3 mg/g ; 633 - $1.000 \mu \mathrm{mol} / \mathrm{m}^{2}$, sedangkan untuk klorofil b yang terdapat pada daun aren bervariasi sekitar 6 - $10 \mu \mathrm{g} / \mathrm{mL}$; 0,4 - 0,7 mg/g ;170 - 293 $\mu \mathrm{mol} / \mathrm{m}^{2}$.

2. Letak posisi daun bagian kiri dan posisi daun bagian kanan pada klrofil a dan klorofil b pada tandan daun aren memiliki jumlah kandungan klorofil yang lebih banyak dibandingkan pada posisi bagian kanan. Letak posisi anak daun pada bagian daun bawah; tengah; atas; dan ujung pada tandan daun juga berbeda satu sama lain. Urutan posisi daun yang memiliki kandungan klorofil a yang paling banyak hingga yang paling sedikit adalah atas;ujung;tengah; dan bawah sedangkan kandungan klorofil b yang paling banyak hingga yang paling sedikit adalah atas;tengah; ujung; dan bawah . Sedangkan posisi pangkal, tengah, dan ujung pada anak daun tidak terlalu memiliki banyak perbedaan (relatif hampir sama penyebaran kandungan klorofilnya).

Daftar Pustaka

Campbell. 2002. Biologi Edisi Kelima Jilid 1. Erlangga, Jakarta.

Gardner. 1991. Fisiologi Tanaman Budidaya. UI Press, Jakarta.

Gogahu, Y., N.S.Ai., dan P.Siahaan. 2016. Konsentrasi Klorofil pada Beberapa Varietas Tanaman Puring (Codiaeum varigatum L.). Jurnal MIPA UNSRAT Online. 5 : 76-80. 
Li, R., P. Guo, M. Baum, S. Grando, S. Ceccarelli. 2006. Evaluation of ChlorophyllContent and Fluoresence Parameters as Indicators of Drought Tolerance in Barley. Agricultural Science in China. $5: 751-757$.

Manatar, J.E., J. Pontoh, dan M.R.J. Runtuwene. 2012. Analisis Kandungan Pati dalam Batang Tanaman Aren (Arenga pinnata). Jurnal IImiah Sains. 12:89-92.

Mustafa,N., N.Ya'acob.,Z.A.Latif., and A.L.Yusof. 2015. Quantification of Oil Palm Tree Leaf Pigment (Chlorophyll A) Concetration Based on Their Age. Jurnal Teknologi. 75 : 129-134.

Nurdin., C.M.Kusharto., I.Tanziha., dan M. Januwati. 2009. Kandungan Klorofil Berbagai Jenis Daun Serta Karakteristik Fisiko-Kimianya.Jurnal Gizi dan Pangan. 4: 13-19.

Pratiwi dan H. Alrasjid, 1989. Teknik Budidaya Aren. Departemen Kehutanan Badan Penelitian dan Pengembangan Kehutanan Pusat Penelitian dan Pengembangan Hutan, Bogor.

Porra,R.J., W. A. Thompson., and P. E. Kricdeman. 1989. Determination of Accurate Extinction Coefficients and Simultaneous Equations for Assaying Chlorophylls $a$ and $b$ Extracted With Four Different Solvents: Verification of the Concentration of Chlorophyll standads by atomic absorption spectroscopy. Biochimia et Biophysica Acta. 975: 384-34.

Pontoh, J dan W. Th. Smits. 2015. Some Aspects Carbohydrate Physiology in Sugar Palm (Arenga pinnata Merr). 8: 13-20.

Sumanta, N., C.I. Haque., J. Nishika., and ., R.Suprakash. 2014. Spectrophotometric Analysis of Chlorophylls and Carotenoids from Commonly Grown Fern Species by Using Various Extracting Solvents. Research Journal of Chemical Sciences. 4:63-69.

Suseno, S. 1991. Bertanam Aren. Penerbit Swadaya, Jakarta.

Wisnuwati. 1996. Manfaat Aren. Balai Pustaka, Jakarta. 